Aspirasi: Jurnal Masalah-Masalah Sosial | Volume 9, No, 2 Desember 2018

ISSN: 2086-6305 (print) ISSN: 2614-5863 (electronic)

DOI: https://doi.org/10.22212/aspirasi.v7il.1084

link online: http://jurnal.dpr.go.id/index.php/aspirasi/index

\title{
KEBIJAKAN PENANGGULANGAN KEJADIAN LUAR BIASA PENYAKIT DEMAM BERDARAH DENGUE DI KABUPATEN TANGERANG
}

\author{
The Policy of Dengue Hemorrhagic Fever Outbreak in Tangerang Regency
}

\author{
Rahmi Yuningsih \\ rahmi.yuningsih@dpr.go.id \\ Pusat Penelitian Badan Keahlian DPR RI \\ Jl. Gatot Subroto Senayan Jakarta
}

Naskah Diterima: 10 Oktober 2018 | Naskah direvisi: 4 Desember 2018 | Naskah diterbitkan: 31 Desember 2018

\begin{abstract}
Tangerang Regency is one of the regions in Indonesia which was declared a Dengue Hemorrhagic Fever (DHF) outbreak. Some policies have been made to respond to this outbreak but they have not been effective in reducing the rate of DHF prevalence. This research is a qualitative study to learn more about DHF outbreak in Tangerang Regency; the policies to control DHF outbreak and the implementation of these policies with their constraints. From 2013 to 2015, there were 373, 412 and 371 DHF cases. In 2016 there were 1,253 DHF cases with 22 deaths. The drastic increase got Tangerang Regency the status of DHF outbreak by the Minister of Health. The implementation of DHF policy focused on mosquito controlling activities, epidemiological investigations, fogging, and handling of DHF patients. There are several obstacles such as the lack of number of health epidemiologists at primary health care and local health officer. This has an impact on the implementation of surveillance and epidemiological activities in detecting DHF outbreak in Tangerang Regency. In addition, efforts to eliminate DHF outbreaks were hampered by the awareness of the people in community who did not prioritize mosquito controlling activities over fogging.
\end{abstract}

Keywords: dengue hemorrhagic fever, outbreak, fogging

Abstrak: Kabupaten Tangerang merupakan salah satu daerah di Indonesia yang dinyatakan Kejadian Luar Biasa (KLB) penyakit Demam Berdarah Dengue (DBD). Permasalahannya, berbagai kebijakan pusat maupun daerah telah dibuat untuk merespons KLB tersebut, namun belum efektif menekan laju prevalensi penyakit DBD. Penelitian ini merupakan penelitian kualitatif dengan tujuan mengetahui KLB penyakit DBD di Kabupaten Tangerang; kebijakan penanggulangan KLB di Kabupaten Tangerang; dan pelaksanaan kebijakan tersebut beserta kendalanya. Dari tahun 2013 hingga 2015, tercatat sebanyak 373, 412, dan 371 kasus DBD. Jumlah tersebut mengalami peningkatan drastis pada tahun 2016 menjadi 1.253 kasus DBD dengan kejadian meninggal sebanyak 22 orang. Peningkatan yang drastis tersebut membuat Kabupaten Tangerang dinyatakan dengan status KLB oleh Menteri Kesehatan. Upaya penanggulangan difokuskan pada kegiatan pemberantasan sarang nyamuk, penyelidikan epidemiologi, fogging, dan penanganan penderita DBD. Dalam pelaksanaannya, terdapat beberapa kendala seperti kurangnya epidemiolog kesehatan di tingkat puskesmas dan kedinasan setempat. Hal ini berdampak pada belum maksimal pelaksanaan kegiatan penyelidikan epidemiologi dalam mendeteksi KLB penyakit DBD di Kabupaten Tangerang. Selain itu, upaya penanggulangan KLB DBD terhambat oleh kesadaran masyarakat yang 
belum mengutamakan kegiatan pemberantasan sarang nyamuk dibanding upaya fogging.

Kata Kunci: demam berdarah, demam berdarah dengue, Kejadian Luar Biasa, wabah, fogging

\section{Pendahuluan}

Secara geografis, Indonesia merupakan negara yang dikelilingi oleh Benua Asia, Benua Australia, Samudra Pasifik, dan Samudera Hindia. Indonesia dilalui oleh garis khatulistiwa sehingga beriklim tropis. Iklim tersebut berdampak pada suhu, curah hujan, pencahayaan, kelembaban, dan angin yang mendukung pertumbuhan dan perkembangan hewan dan tumbuhan, termasuk vektor penyakit. Banyaknya vektor penyakit yang berkembang subur di iklim tropis, membuat Indonesia menjadi daerah endemis penyakit menular. Salah satunya adalah penyakit Demam Berdarah Dengue (DBD) yang disebabkan oleh gigitan vektor nyamuk Aedes aegypti yang telah terinfeksi virus dengue. Penyakit DBD pertama kali ditemukan di Indonesia, yaitu di Kota Surabaya pada tahun 1968. Pada saat itu, tercatat sebanyak 58 orang terinfeksi dan 24 orang di antaranya meninggal dunia. ${ }^{1}$ Sejak saat itu, penyakit DBD menyebar ke berbagai daerah, sehingga sampai tahun 1980 seluruh provinsi di Indonesia telah terjangkit penyakit DBD.

Berdasarkan data Kementerian Kesehatan, secara nasional pada tahun 2017 kasus DBD berjumlah 68.407 kasus dengan jumlah kematian sebanyak 493 orang. Jumlah tersebut menurun cukup drastis dari tahun 2016, yaitu 204.171 kasus dengan jumlah kematian sebanyak 1.598 orang. Prevalensi DBD tahun 2017 juga menurun jika dibandingkan dengan tahun 2016, yaitu dari 78,85 menjadi 26,10 per 100.000 penduduk. Namun, penurunan Case Fatality Rate (CFR) dari tahun sebelumnya tidak terlalu tinggi, yaitu 0,78\% pada tahun 2016 menjadi 0,72\% pada tahun 2017 (Kementerian Kesehatan, 2018). Angka kesakitan penyakit DBD dari tahun 2010 hingga 2017 ditunjukkan pada Grafik 1.

Epidemiologi dan Pemberantasan Demam Berdarah Dengue (DBD) di Indonesia, http://repository.usu.ac.id/ bitstream/ $123456789 / 3673 / 3 / \mathrm{fkm}$-fazidah3.pdf.txt, diakses 26 September 2018 .

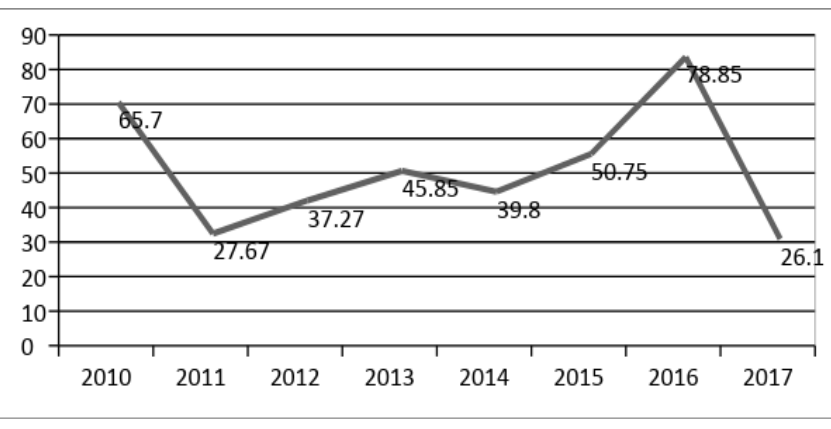

\section{Grafik 1. Angka Kesakitan Penyakit DBD dari Tahun 2010-2017}

Sumber: Profil Kesehatan Indonesia Tahun 2017. (2018). Kementerian Kesehatan

Dari grafik tersebut terlihat angka kesakitan DBD kembali naik pada tahun 2010, 2013, dan 2016 setelah dua tahun sebelumnya mengalami penurunan. Penyebaran DBD hingga menjadi wabah atau Kejadian Luar Biasa (KLB) juga menjadi hal yang harus diwaspadai. Kementerian Kesehatan mencatat pada tahun 2014, jumlah kasus KLB DBD yang dilaporkan meningkat dari 1.081 kasus pada tahun 2014 menjadi 8.030 kasus pada tahun 2015. Demikian juga dengan jumlah provinsi dan kabupaten yang melaporkan KLB DBD meningkat, yaitu 5 provinsi dan 21 kabupaten pada tahun 2014 menjadi 7 provinsi dan 69 kabupaten pada tahun 2015.

Di tingkat provinsi, Banten merupakan salah satu provinsi yang memiliki CFR DBD tinggi, yaitu 1,34\%. Angka nasional untuk CFR DBD pada tahun 2017 hanya $0,72 \%$. CFR merupakan ukuran derajat keganasan atau kegawatan dari suatu penyakit untuk dapat menyebabkan kematian pada suatu komunitas pada kurun waktu tertentu. Tingginya CFR menandakan terlambatnya upaya pemberantasan penyakit DBD termasuk terlambatnya upaya pengobatan sehingga menyebabkan kematian pada penderita DBD.

Di Provinsi Banten, Kabupaten Tangerang merupakan wilayah dengan kasus DBD tertinggi. Setiap tahun, penyakit DBD terjadi di Kabupaten 
Tangerang dengan puncaknya setiap tiga tahun sekali seperti yang terjadi pada tahun 2013 (373 kasus DBD) dan 2016 (1.253 kasus DBD dengan 22 kematian). ${ }^{2}$ Dengan kata lain, CFR DBD Kabupaten Tangerang pada tahun 2016 sebesar 1,75\%. Persentase CFR tersebut lebih tinggi dari CFR nasional dan CFR Provinsi Banten. Berdasarkan tingginya kasus DBD tersebut, pada bulan Februari 2016, Menteri Kesehatan menetapkan Kabupaten Tangerang dengan status KLB penyakit DBD. ${ }^{3}$ Atas dasar penetapan tersebut, Pemerintah Kabupaten Tangerang kemudian menetapkan kasus DBD yang terjadi saat itu sebagai KLB. ${ }^{4} \mathrm{Hal}$ ini guna memudahkan penggerakkan semua komponen pemerintah daerah dalam upaya pemberantasan KLB penyakit DBD. Kecamatan Panongan, Balaraja, Curug, Cikupa, Pasar Kemis, dan Legok merupakan wilayah endemis DBD di Kabupaten Tangerang.

Penyebaran penyakit DBD hingga menjadi KLB sangat terkait dengan perilaku masyarakat dalam menjaga kebersihan dan kesehatan lingkungan. Keberadaan vektor nyamuk di tempat perindukan di tempat penampungan air bersih seperti bak mandi, tempayan, ember, kaleng bekas, vas bunga, dan lainnya juga menjadi faktor yang perlu diperhatikan sehingga pemberantasan dilakukan melalui pendekatan perubahan perilaku, kebersihan lingkungan dan pemberantasan tempatperindukannyamuk. Ketika sudah ada penderita DBD di tengah masyarakat, biasanya permintaan dilakukannya fogging atau pengasapan akan meningkat. Pemerintah telah menyatakan penyakit DBD sebagai salah satu penyakit yang dapat menimbulkan wabah atau KLB. Hal ini sebagaimana tertera dalam Peraturan Menteri Kesehatan Nomor 1501/

2 Demam Berdarah di Kabupaten Tangerang Makin Parah, http://wartakota.tribunnews. com/2016/03/29/demamberdarah-di-kabupaten-tangerang-makin-parah diakses 6 September 2018.

3 Bersama 10 Daerah Lainnya, Kabupaten Tangerang Dinyatakan KLB Demam Berdarah, http://poskotanews. com/2016 /02/05/kabupaten-tangerang-dinyatakan-klbdemam-berdarah/ diakses 6 September 2018.

413 Orang Meninggal, Kabupaten Tangerang Tetapkan KLB DBD, https://metro.tempo. co/read/742330/13-orangmeninggal-kabupaten-tangerang-tetapkan-klb-dbd diakses 6 September 2018.
Menkes/Per/X/2010 tentang Jenis Penyakit Menular Tertentu yang Dapat Menimbulkan Wabah dan Upaya Penanggulangan.

Selain itu, merebaknya kasus DBD bahkan sampai menimbulkan KLB juga disebabkan oleh lambannya pemerintah dalam mengantisipasi dan merespons kasus DBD ${ }^{5}$. Hasil penelitian Runge-Ranzinger menyebutkan bahwa sebagian besar negara yang diteliti tidak memiliki rencana kontijensi yang komprehensif dan rinci untuk wabah DBD. Negara-negara cenderung bergantung pada kontrol vektor yang diintensifkan sebagai respons wabah, dengan intervensi yang sangat minimal pada aspek manajemen terpadu perawatan klinis, epidemiologi, laboratorium dan surveilans. Untuk itu dibutuhkan buku pegangan teknis untuk surveilans, prediksi wabah, dan respons wabah yang merupakan pedoman praktik terbaik berdasarkan bukti untuk memastikan status wabah dan mobilisasi sumber daya yang diperlukan dalam rencana kontijensi dengue yang efektif (Runge-Ranzinger, 2016).

Seperti yang telah disebutkan sebelumnya, bahwa penyakit DBD merupakan penyakit menular yang terjadi setiap tahun bahkan mengalami peningkatan jumlah penderita setiap tiga tahun sekali dan menyebabkan status KLB. Kebijakan yang ada belum mampu mengatasi penyakit DBD yang sering terjadi. Diperlukan upaya untuk mewaspadai meningkatnya kasus DBD dan KLB DBD berdasarkan evaluasi dari pelaksanaan kebijakan penanggulangan KLB DBD yang telah dilakukan. Oleh karenanya, pertanyaan penelitian ini adalah bagaimana KLB penyakit DBD di Kabupaten Tangerang? Apa saja kebijakan penanggulangan KLB di Kabupaten Tangerang? Bagaimana implementasi kebijakan tersebut di tingkat puskesmas? Sedangkan tujuan penelitian ini adalah untuk mengetahui KLB penyakit DBD di Kabupaten Tangerang, kebijakan penanggulangan KLB di Kabupaten Tangerang, dan implementasi kebijakan tersebut di tingkat puskesmas.

\footnotetext{
Implementasi Kebijakan Pemerintah mengenai Pengendalian Penyakit Demam Berdarah (DBD) dalam Rangka Meningkatkan Derajat Kesehatan Masyarakat di Kota Semarang, http://ejournal.stikestelogorejo.ac.id/index. php/ilmukeperawatan/article/viewFile/289/313, diakses 26 September 2018.
} 
Penelitian ini merupakan penelitian kualitatif yang dilakukan di Kabupaten Tangerang pada tanggal 30 Juli hingga 6 Agustus 2018. Data primer dikumpulkan melalui wawancara mendalam kepada informan yang dipilih secara purposive seperti kepala bidang penyakit menular, pengelola program pengendalian penyakit menular dan tenaga kesehatan masyarakat di Dinas Kesehatan Kabupaten Tangerang, tenaga epidemiologi, tenaga medis dan staf di puskesmas serta akademisi epidemiologi di UMJ. Data sekunder didapat melalui buku, peraturan perundanganundangan, jurnal, berita media massa, dan lainnya. Data dikumpulkan dan dikelompokkan menurut poin-poin pembahasan. Tahap terakhir adalah pembuatan kesimpulan atau verifikasi dari pertanyaan penelitian.

\section{Epidemiologi Penyakit DBD}

Epidemiologi merupakan studi tentang penyebaran penyakit serta faktor-faktor yang memengaruhinya. Penyebaran penyakit dikaji melalui frekuensi penyakit yang dihitung dalam angka prevalensi, insiden, CFR, dan lainnya. Kegunaan epidemiologi adalah untuk menggambarkan penyakit yang terjadi di masyarakat secara keseluruhan berdasarkan frekuensi, distribusi, dan determinan yang memengaruhinya. Terdapat tiga hal yang memengaruhi terjadinya penyakit menular atau biasa disebut segitiga epidemiologi penyakit menular, yaitu agent, host dan environment. Ketiganya saling memengaruhi satu sama lain. Agen merupakan penyebab penyakit menular seperti virus, bakteri, protozoa, jamur, cacing, riketsia, dan lainnya. Agen penyakit dapat bertahan di tubuh manusia dan juga binatang (zoonosis). Host atau induk semang dapat terinfeksi agen penyakit namun tergantung pada kekebalan tubuhnya. Sedangkan environment merupakan media kontak antara agen dan induk semang, yaitu berupa udara, sentuhan kulit, makanan yang telah terkontaminasi, plasenta ibu hamil, dan lainnya.

Pada penyakit DBD, agen penyakit menular berupa virus dengue yang termasuk dalam famili Flaviridae dan genus Flavivirus, terdiri dari empat serotipe, yaitu Den-1, Den-2, Den-3 dan Den-4. Virus ditularkan kepada manusia (host) melalui perantara gigitan vektor nyamuk Aedes aegypti dan Aedes albocpictus yang terinfeksi virus dengue. Pada mulanya nyamuk tersebut berasal dari negara Mesir yang kemudian menyebar ke seluruh dunia termasuk Indonesia melalui transportasi udara dan laut. Nyamuk tersebut hidup dengan subur di belahan dunia yang mempunyai iklim tropis dan subtropis seperti Benua Asia, Afrika, Australia dan Amerika.

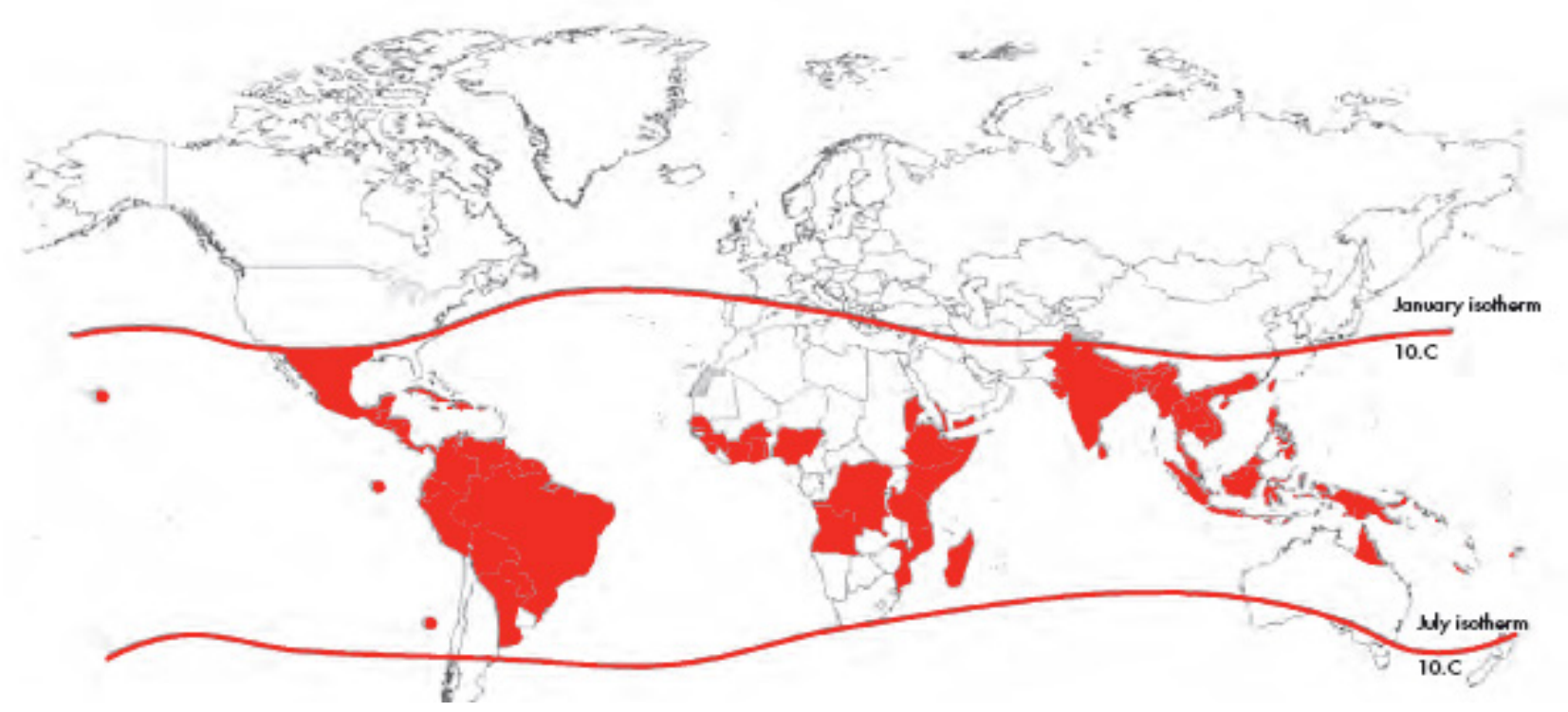

Gambar 1. Peta Penyebaran Risiko Penyakit DBD

Sumber: WHO, 2009. 
DBD merupakan beban kesehatan masyarakat yang besar dan dapat menyebabkan tingginya tingkat morbiditas dan mortalitas yang signifikan di sebagian besar dunia (Rothman, 2016). Di Indonesia, nyamuk Aedes tersebar luas di seluruh pelosok tanah air kecuali di wilayah yang ketinggiannya lebih dari 1.000 meter di atas permukaan laut. Faktor-faktor yang memengaruhi peningkatan dan penyebaran kasus DBD antara lain pertumbuhan penduduk yang tinggi, urbanisasi yang tidak terencana dan tidak terkendali, kontrol vektor nyamuk yang tidak efektif di daerah endemis, dan peningkatan sarana transportasi.

Menurut Philip dan Silaban, curah hujan yang rendah dan dalam waktu yang lama akan menambah tempat perindukan nyamuk dan meningkatkan populasi nyamuk. Cahaya berpengaruh pada kebiasaan nyamuk untuk mencari makan atau tempat beristirahat. Karena terdapat spesies nyamuk yang meninggalkan tempat istirahat setelah 20-30 menit matahari terbenam. Nyamuk Aedes aegypti memiliki kebiasaan beristirahat di tempat yang gelap dan terlindung dari sinar matahari, begitu pula dalam kebiasaan meletakkan telur. Kelembaban dapat mempengaruhi transmisi vektor. Kemampuan nyamuk dalam bertahan hidup mengalami penurunan pada kondisi kering. Rata-rata kelembaban telah ditemukan sebagai faktor paling kritis pada penyakit. Kecepatan angin akan memengaruhi penyebaran nyamuk Aedes aegypti. Kecepatan angin akan mempengaruhi daya jangkau terbang nyamuk Aedes aegypti. Semakin luas daya jangkau nyamuk, maka semakin banyak kesempatan untuk kontak dengan manusia sehingga umur dan masa reproduksi nyamuk akan semakin panjang (Dini, 2010).

Spektrum klinis penyakit DBD berkisar dari penyakit tanpa gejala hingga berbagai macam sindrom dengan manifestasi klinis yang parah. Gejala infeksi dapat berkisar dari dengue fever ringan hingga Dengue Hemoragic Fever (DHF) dan Dengue Shock Syndrome (DSS) yang menyebabkan pendarahan yang berlebihan, gangguan organ, dan pelepasan plasma darah. Dalam kasus yang parah, dapat mengancam jiwa jika tidak ditangani dengan benar. DSS ditandai dengan nadi yang cepat dan tekanan nadi yang menyempit (<20 mm Hg) (Khetarpal, 2016).

Gejala klinis DBD ditandai dengan demam mendadak, sakit kepala, nyeri, mual, dan menifestasi perdarahan seperti mimisan atau gusi berdarah serta adanya kemerahan di bagian permukaan tubuh pada penderita. Pada umumnya penderita DBD akan mengalami fase demam selama 2-7 hari. Fase pertama terjadi selama satu hingga tiga hari. Penderita akan merasakan demam yang cukup tinggi, yaitu $40^{\circ} \mathrm{C}$. Pada fase kedua, penderita mengalami fase kritis pada hari keempat hingga kelima. Pada fase ini penderita akan mengalami penurunan suhu tubuh hingga $37^{\circ} \mathrm{C}$ dan penderita akan merasa dapat melakukan aktivitas kembali (merasa sembuh kembali). Pada fase ini jika tidak mendapatkan pengobatan yang adekuat, dapat terjadi keadaan fatal, yaitu penurunan trombosit secara drastis akibat pemecahan pembuluh darah (pendarahan). Selanjutnya fase ketiga akan terjadi pada hari kelima dan keenam di mana penderita akan merasakan demam kembali. Fase ini dinamakan fase pemulihan di mana trombosit akan perlahan naik dan normal kembali (Kementerian Kesehatan, 2017). Sampai saat ini, DBD masih menjadi masalah kesehatan bagi masyarakat dan menimbulkan dampak sosial maupun ekonomi. Kerugian sosial yang terjadi antara lain munculnya kepanikan dalam keluarga, kematian anggota keluarga, berkurangnya usia harapan dalam keluarga, dan berkurangnya usia harapan hidup masyarakat. Dampak ekonomi langsung adalah biaya pengobatan yang cukup mahal, sedangkan dampak tidak langsung adalah kehilangan waktu kerja dan biaya lain yang dikeluarkan selain pengobatan seperti transportasi dan akomodasi selama perawatan sakit.

Upaya pemberantasan penyakit DBD dititikberatkan pada pemberantasan nyamuk penularnya, di samping kewaspadaan dini terhadap kasus DBD untuk membatasi angka kematian. Pemberantasan nyamuk dilakukan melalui penyemprotan insektisida. Namun selama jentiknya masih dibiarkan hidup, maka akan timbul lagi kasus baru nyamuk DBD. 
Penyemprotan sebaiknya dibatasi pada wilayah yang berpotensi wabah atau KLB. Selain penyemprotan insektisida, pemberantasan nyamuk juga dilakukan di tempat perindukan nyamuk. Tempat perindukan vektor nyamuk Aedes dipengaruhi oleh jenis, ukuran dan warna wadah, air, suhu, kelembaban, dan kondisi lingkungan setempat. Tempat perindukan jentik nyamuk Aedes paling banyak di Tempat Penampungan Air (TPA) yang terbuat dari logam, semen, kayu dan yang paling sedikit yang terbuat dari keramik. Hal ini dikarenakan ada hubungannya dengan ketersediaan makanan larva yang menempel di dinding TPA. Jentik banyak ditemukan di wadah TPA yang berukuran besar seperti tempayan, drum, dan bak mandi (Hasyimi dan Mardjan, 2004). Penyimpanan air di wadah bermuatan besar cenderung membutuhkan waktu lama untuk menggunakannya.

Sebagaimana dengan penyakit yang disebabkan oleh virus, banyak kelompok ahli yang telah melakukan upaya intensif dan membuat kemajuan dalam mengembangkan vaksin yang aman, terjangkau dan efektif terhadap semua serotipe virus dengue. Seperti upaya mengkaji vaksin dengue melalui pengembangan virus dengue yang telah dilemahkan, virus dengue yang tidak aktif, vaksin sub-unit, vaksin DNA, dan penggabungan vaksin yellow fever dengan virus dengue yang dilemahkan. Namun hingga saat ini tidak ada vaksin yang efektif untuk melawan virus dengue (Nedjadi, 2015). Pengembangan vaksin dengue merupakan tugas yang berat karena adanya empat serotipe virus dengue dengan antigen yang berbeda, masing-masing mampu memunculkan respon antibodi yang justru dapat meningkatkan penyakit terhadap tiga serotipe lainnya (Khetarpal, 2016). Termasuk vaksin DBD dengvaxia yang dibuat oleh perusahaan farmasi Perancis, yaitu Sanofi Pasteur. Vaksin telah beredar secara komersial di 11 negara endemis DBD termasuk Asian Tenggara dan Brasil. Setelah dilakukan penelitian selama enam tahun, dengvaxia dapat memicu munculnya penyakit yang lebih parah pada orang yang belum pernah terinfeksi virus dengue. ${ }^{6}$ Sehingga upaya

Efek Vaksin DBD Bisa Berbahaya, Ini Penjelasan WHO dan IDAI, https://sains. kompas.com/ penanggulangan KLB DBD difokuskan pada perubahan perilaku masyarakat untuk senantiasa memberantas nyamuk dan jentiknya.

\section{Kebijakan Penanggulangan KLB DBD}

Kebijakan publik merupakan serangkaian tindakan yang mempunyai tujuan tertentu yang diikuti dan dilaksanakan oleh seorang pelaku atau sekelompok pelaku guna memecahkan suatu masalah tertentu. Proses pembuatan kebijakan publik bermula dari penyusunan agenda, formulasi, adopsi, implementasi, dan penilaian kebijakan. Proses tersebut mencerminkan aktivitas yang terus berlangsung yang terjadi sepanjang waktu (Dunn, 2003). Implementasi kebijakan publik terdiri dari indikator ukuran dan tujuan kebijakan; sumber daya yang terdiri dari SDM, finansial dan waktu; karakteristik agen pelaksana; sikap atau kecenderungan para pelaksana; komunikasi antarorganisasi dan aktivitas pelaksana; dan lingkungan ekonomi, sosial dan politik (Agustino, 2008).

Kebijakan publik dalam bentuk undangundang mengenai penanggulangan wabah penyakit menular tertera dalam Undang-Undang Nomor 4 Tahun 1984 tentang Wabah Penyakit Menular (UU WPM). Undang-undang tersebut merupakan pengganti dari Undang-Undang Nomor 6 Tahun 1962 tentang Wabah yang dinilai kurang mengakomodir perkembangan teknologi, ilmu pengetahuan, lalu lintas internasional, dan perubahan lingkungan hidup yang dapat memengaruhi perubahan pola penyakit. Dalam ketentuan umum disebutkan bahwa wabah adalah kejadian berjangkitnya suatu penyakit menular dalam masyarakat yang jumlah penderitanya meningkat secara nyata melebihi dari pada keadaan yang lazim pada waktu dan daerah tertentu serta dapat menimbulkan malapetaka. Maksud dan tujuan adanya undang-undang tersebut adalah untuk melindungi penduduk dari malapetaka yang ditimbulkan oleh wabah sedini mungkin, dalam rangka meningkatkan kemampuan masyarakat untuk hidup sehat. Menteri mempunyai wewenang menetapkan

$\mathrm{read} / 2017 / 12 / 08 / 170000223 /$ efek-vaksin-dbd-bisaberbahaya-ini-penjelasan-who-dan-idai, diakses 26 September 2018. 
dan mencabut penetapan daerah tertentu dalam wilayah Indonesia yang terjangkit wabah sebagai daerah wabah. Upaya penanggulangan wabah meliputi penyelidikan epidemiologis; pemeriksaan, pengobatan, perawatan, dan isolasi penderita termasuk tindakan karantina; pencegahan dan pengebalan; pemusnahan penyebab penyakit; penanganan jenazah akibat wabah; penyuluhan kepada masyarakat; dan upaya penanggulangan lainnya.

Kebijakan publik dalam bentuk undangundang adalah jenis kebijakan publik yang memerlukan kebijakan publik penjelas atau peraturan pelaksananya (Nugroho, 2012). Begitu pula dengan Undang-Undang Nomor 4 Tahun 1984 tentang Wabah Penyakit Menular yang memerlukan peraturan pelaksananya. Undangundang tersebut mengamanatkan pembentukan enam peraturan pemerintah dan satu peraturan menteri sebagai peraturan pelaksana UU WPM. Namun hingga kini hanya ada satu peraturan pelaksana, yaitu Peraturan Pemerintah Nomor 40 Tahun 1991 tentang Penanggulangan Wabah Penyakit Menular yang isinya merupakan gabungan dari enam peraturan pemerintah tersebut. Selain itu, terdapat Peraturan Menteri Kesehatan Nomor 949/Menkes/Per/ VIII/2004 tentang Pedoman Penyelenggaraan Sistem Kewaspadaan Dini Kejadian Luar Biasa (KLB) yang mengutamakan kajian epidemiologi dalam deteksi KLB.

Terkait vektor DBD, pengendalian vektor penyakit menular diatur dalam Peraturan Menteri Kesehatan Nomor 374/Menkes/Per/
III/2010 tentang Pengendalian Vektor. Pasal 5 menyebutkan bahwa pengendalian vektor dapat dilakukan dengan pengelolaan lingkungan secara fisik atau mekanis, penggunaan agen biotik, kimiawi baik terhadap vektor maupun tempat perkembangbiakannya dan/atau perubahan perilaku masyarakat serta dapat mempertahankan dan mengembangkan kearifan lokal sebagai alternatif. Selain itu, kebijakan penanggulangan DBD tertera dalam Keputusan Menteri Kesehatan Nomor 92/Menkes/SK/II/1994 tentang Perubahan atas Lampiran Keputusan Menteri Nomor 581/ Menkes/SK/VII/1992 tentang Pemberantasan Penyakit Demam Berdarah Dengue, Pokja DBD dibentuk di tingkat desa atau kelurahan dan dapat juga dibentuk di tingkat wilayah di bawah desa atau kelurahan seperti dusun, RT dan RW. Pokja DBD dibentuk melalui pertemuan atau musyawarah masyarakat yang dihadiri oleh pengurus LKMD dan tokoh masyarakat sesuai dengan prosedur dan mekanisme yang ada. Struktur organisasi dan susunan pengurus Pokja DBD serta pembagian tugas masing-masing anggota ditetapkan melalui forum musyawarah masyarakat, yang kemudian disahkan oleh kepala desa atau kepala kelurahan selaku ketua umum LKMD.

Atas dasar kejadian KLB 2016, Kementerian Kesehatan mendorong masyarakat melakukan upaya pencegahan dan pengendalian DBD melalui Pemberantasan Sarang Nyamuk (PSN) 3M Plus dengan "Gerakan Satu Rumah Satu Jumantik (Juru Pemantau Jentik)" melalui Surat Edaran Nomor PM.01.11/Menkes/591/2016

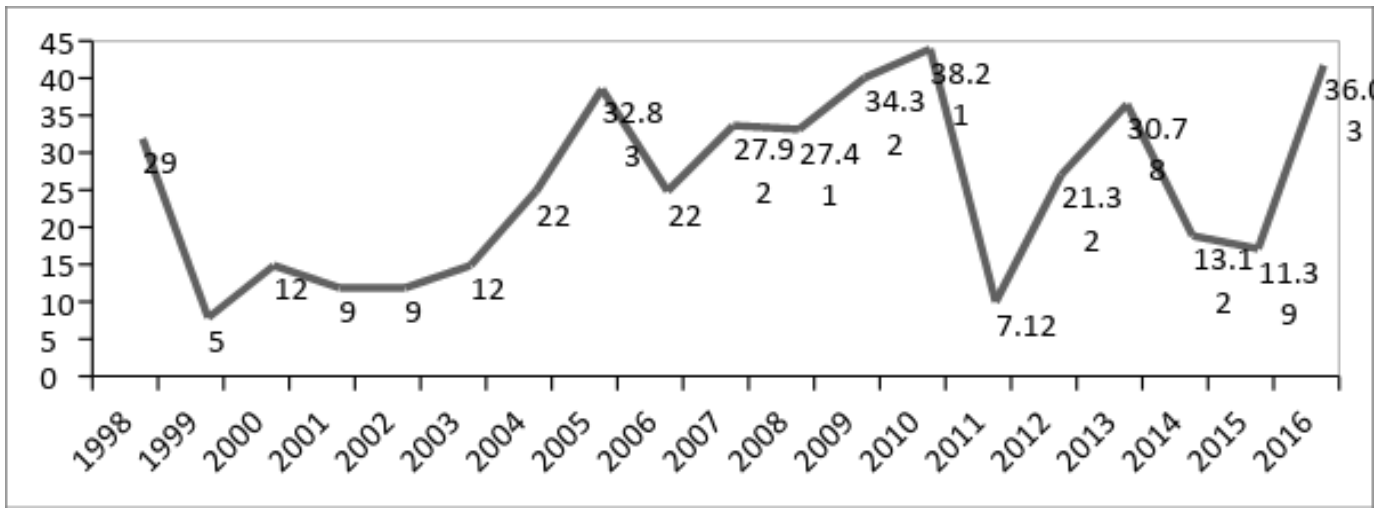

Grafik 3. Angka Insiden DBD Kabupaten Tangerang dari Tahun 1998-2016 Sumber: Dinas Kesehatan Kabupaten Tangerang, 2017. 


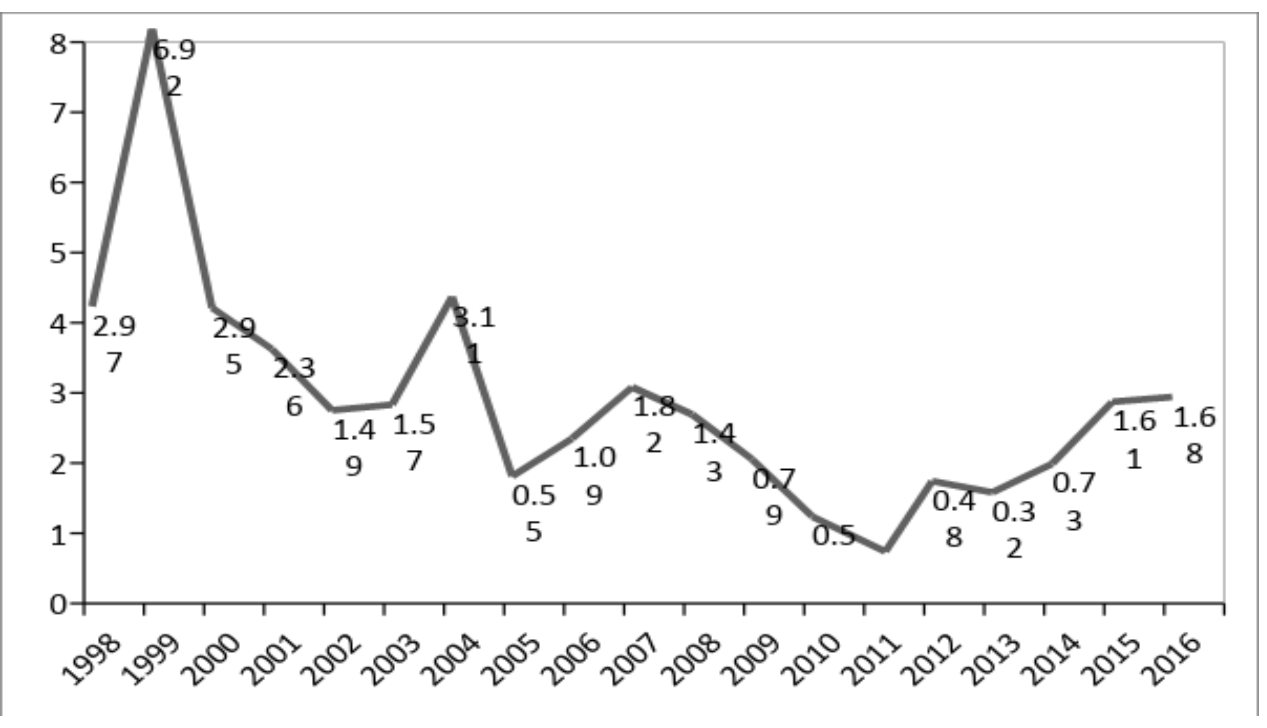

Grafik 4. Grafik CFR DBD Kabupaten Tangerang dari Tahun 1998-2016 Sumber: Dinas Kesehatan Kabupaten Tangerang, 2017.

tentang Pelaksanaan Pemberantasan Sarang Nyamuk 3M Plus dengan "Gerakan Satu Rumah Satu Jumantik". Upaya tersebut antara lain:

1. Menguras, yaitu membersihkan tempat yang sering dijadikan tempat penampungan air seperti bak mandi, ember air, tempat penampungan air minum, dan penampungan air di lemari es dan dispenser.

2. Menutup, yaitu menutup rapat-rapat tempat penampungan air seperti drum, kendi, dan toren air.

3. Memanfaatkan kembali atau mendaur ulang barang bekas yang memiliki potensi untuk menjadi tempat perkembangbiakan nyamuk Aedes.

Adapun yang dimaksud dengan "plus" adalah segala bentuk kegiatan pencegahan dari gigitan nyamuk seperti:

1. Menaburkan atau meneteskan larvasida pada tempat penampungan yang sulit dibersihkan.

2. Menggunakan obat nyamuk atau anti nyamuk.

3. Menggunakan kelambu saat tidur.

4. Memelihara ikan pemangsa jentik nyamuk.

5. Menanam tanaman pengusir nyamuk.

6. Mengatur cahaya dan ventilasi dalam rumah.

7. Menghindari kebiasaan menggantung pakaian di dalam rumah yang dapat menjadi tempat istirahat nyamuk.

8. Mulai menggunakan air pancur untuk mandi dengan tujuan mengurangi penggunaan bak mandi.

Sementara "Gerakan Satu Rumah Satu Jumantik" dilakukan di lingkungan rumah tempat tinggal dengan upaya:

1. Mengajak keluarga dan tetangga di lingkungan sekitar untuk menjadi Jumantik dan melakukan pemantauan jentik nyamuk serta kegiatan PSN 3M plus di rumah masingmasing

2. Berkoordinasi dengan ketua atau pengurus RT setempat dengan membentuk Jumantik di lingkungan setempat dan membentuk supervisor Jumantik.

Strategi pencegahan dan pengendalian KLB DBD dilakukan dengan upaya melakukan surveilans aktif berbasis laboratorium, kesiapan dan tanggap darurat untuk pengendalian nyamuk, darurat rawat inap dan pengobatan penderita DBD, pendidikan kesehatan masyarakat tentang diagnosis klinis dan manajemen DBD, pengendalian nyamuk Aedes di komunitas (Gubler, 2005). Menurut Kementerian Kesehatan, fogging bukan strategi yang utama dalam mencegah DBD. Fogging tidak dilakukan secara rutin melainkan dilakukan di daerah sekitarnya pada saat terjadinya kasus di suatu wilayah. Pencegahan dilakukan melalui menjaga kebersihan dan menghilangkan jentik nyamuk. Upaya pemusnahan nyamuk dewasa dengan 
metode ultra-low-volume fogging merupakan kegagalan kebijakan yang terjadi di negaranegara endemis DBD di Amerika. Ketika pandemi DBD terjadi, biasanya respon untuk menerapkan penyemprotan fogging kembali meningkat. Metode ini dinilai tidak efektif karena membutuhkan biaya yang tidak sedikit dan dampak yang tidak adekuat pada transmisi nyamuk. Walaupun kegiatan fogging telah dilakukan, namun tetap terjadi puluhan ribu kasus DBD, ratusan kematian, dan ratusan juta dolar dalam kerugian ekonomi (Gubler, 2005).

Manajemen lingkungan merupakan upaya pengendalian vektor yang paling efektif, yaitu:

1. Mengurangi habitat vektor seperti menutup tempat penyimpanan air, membuang limbah padat yang dapat menjadi tempat perindukan nyamuk.

2. Penggunaan bilogi seperti predator nyamuk seperti capung, katak, dan ikan.

3. Penggunaan bahan kimia yang memiliki sifat insektisida guna mengurangi populasi nyamuk di lingkungan setempat seperti larvasida yang diterapkan langsung ke air dan adulticides yang digunakan dalam fogging untuk melawan nyamuk dewasa. Contoh insektisida yang digunakan adalah organofosfat seperti fenitrothion, fenthione malathione, dan piretroid seperti cypermethin, deltamethrin, dan permethrin (WHO, 2009).

Manajemen vektor terintegrasi merupakan pengambilan keputusan yang rasional dalam mengoptimalkan penggunaan sumber daya yang optimal dalam pengendalian vektor. Tujuannya membuat kontrol terhadap vektor yang lebih efisien, hemat biaya, ekologis, dan berkelanjutan. Perencanaan dan implementasi pengendalian vektor melibatkan analisis determinan lokal penyakit, menilai persyaratan dan sumber daya, dan merancang strategi lokal. Terdapat lima elemen kunci dari strategi tersebut, yaitu:

1. Advokasi, mobilisasi sosial, dan legislasi.

2. Kolaborasi dalam sektor kesehatan dan dengan sektor lain.

3. Pendekatan terpadu.

4. Pengambilan keputusan berdasarkan bukti.

5. Peningkatan kapasitas (WHO, 2009).
Dengan kata lain, pendekatan untuk meningkatkan kesehatan lingkungan dan mengelola habitat vektor seharusnya menjadi prioritas dalam penanggulangan KLB DBD. Kontrol vektor DBD merupakan alat yang efektif dalam mengurangi populasi nyamuk Aedes terutama melalui pendekatan berbasis komunitas dan dikombinasikan dengan pendidikan kesehatan dalam meningkatkan pengetahuan, kesadaran, dan sikap masyarakat. Dalam upaya penanggulangan penyakit DBD yang efektif, diperlukan koordinasi lintas sektor yang terkait sanitasi, pengembangan perkotaan dan sektor pendidikan. Selain itu, harus melibatkan komunitas lokal dalam melindungi diri mereka sendiri dengan upaya pemusnahan tempat perindukan nyamuk, penggunaan obat nyamuk, dan lainnya (Singh, 2017).

\section{Prevalensi Penyakit DBD di Kabupaten Tangerang}

Penyakit DBD di Kabupaten Tangerang biasanya terjadi di awal tahun dengan puncak penemuan kasus pada minggu kelima atau akhir bulan Januari. Setelah minggu kelima, kejadian DBD mengalami fluktuasi namun cenderung menurun hingga akhir tahun. Bulan Januari merupakan musim penghujan di mana musim yang kondusif untuk perkembangbiakan nyamuk. Hal ini sesuai dengan pernyataan Kementerian Kesehatan, yaitu setiap tahun kejadian DBD di Indonesia cenderung meningkat pada pertengahan musim penghujan sekitar bulan Januari dan cenderung turun pada bulan Februari hingga ke penghujung tahun (Kementerian Kesehatan, 2016).

Grafik 2 menunjukan jumlah kejadian penyakit DBD dari tahun ke tahun cenderung fluktuatif dan terlihat mencapai puncaknya pada tahun 2010, 2013 dan 2016. Bahkan dibandingkan dengan tahun sebelumnya, jumlah kejadian tahun 2016 mencapai tiga kali lipat dari tahun 2015. Tingginya kejadian DBD pada tahun 2016, membuat pemerintah daerah menetapkan status KLB. 


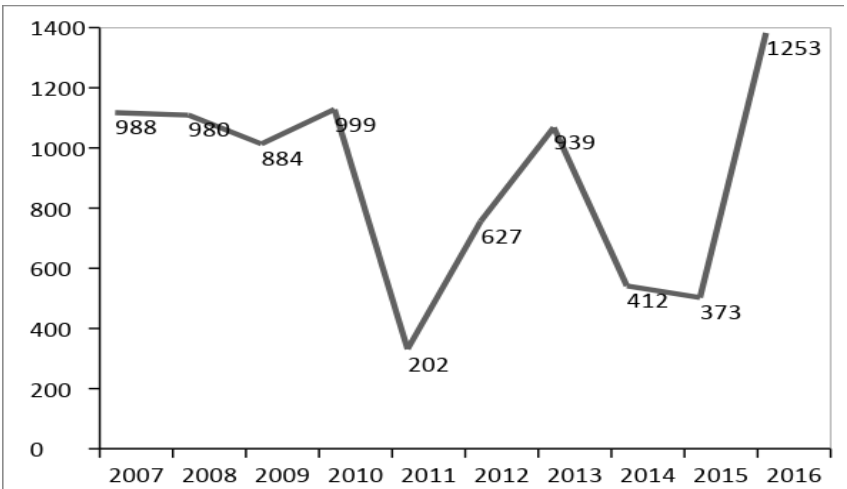

Grafik 2. Jumlah Kejadian DBD Kabupaten Tangerang dari Tahun 2007-2016

Sumber: Dinas Kesehatan Kabupaten Tangerang, 2017.

Jumlah kejadian DBD di Kabupaten Tangerang dilihat dari angka insiden (incidence rate) atau kasus baru setiap tahunnya, ternyata mengalami fluktuasi dan mencapai puncak setiap tiga tahun, yaitu tahun 2010 sebesar 38,21 per 100.000 penduduk, tahun 2013 sebesar 30,78 per 100.000 penduduk, dan tahun 2016 sebesar 36,03 per 100.000 penduduk. Dengan kata lain, pada tahun 2016 , terdapat 36 orang yang baru terinfeksi penyakit DBD dari 100.000 penduduk Kabupaten Tangerang. Angka insiden DBD Kabupaten Tangerang dari tahun 1998 hingga 2016 akan ditunjukkan dalam grafik 3 berikut.

Berdasarkan Grafik 3 terlihat bahwa epidemi DBD mencapai puncaknya setiap tiga hingga lima tahun. Wilayah cakupan puskesmas di Kabupaten Tangerang yang memiliki kasus DBD terbanyak adalah wilayah Panongan, Cikupa, Balaraja, Sukamulya, Kresek, Sindang Jaya, Tigaraksa, Curug, Cisoka, dan Cikuya. Hal ini terjadi karena pengaruh kepadatan penduduk, mobilitas penduduk yang tinggi, dan sarana transportasi yang lebih baik dibanding daerah lain, sehingga penyebaran virus menjadi lebih mudah dan lebih luas.

Selain jumlah kejadian dan angka insiden, terdapat perhitungan epidemiologi lain yang digunakan untuk mengetahui persebaran penyakit, yaitu CFR atau angka kematian. Grafik 3 berikut menunjukkan CFR DBD di Kabupaten Tangerang dari tahun 1998 hingga 2016.

CFR merupakan ukuran derajat keganasan atau kegawatan dari suatu penyakit untuk dapat menyebabkan kematian pada suatu komunitas pada kurun waktu tertentu. Angka nasional CFR DBD adalah di bawah $1 \%$, yaitu $0,72 \%$. Namun CFR kasus DBD di Kabupaten Tangerang di atas angka nasional, yaitu sebesar 2,95\% pada tahun 2000, turun menjadi $1,61 \%$ pada tahun 2015 dan naik kembali menjadi 1,75\% pada tahun 2016. Tingginya CFR menandakan terlambatnya upaya pemberantasan penyakit DBD termasuk terlambatnya upaya pengobatan sehingga menyebabkan kematian pada penderita DBD. Grafik 4 memperlihatkan bahwa secara umum telah terjadi penurunan tren CFR dari 1998 hingga 2016. Hal ini dapat disebabkan oleh semakin baiknya akses pelayanan kesehatan.

\section{Implementasi Kebijakan Penanggulangan KLB DBD di Kabupaten Tangerang}

Permasalahan pembangunan kesehatan yang tertera dalam RPJMD Kabupaten Tangerang Tahun 2013-2018 antara lain masih ditemukannya KLB penyakit menular, masih rendahnya partisipasi masyarakat dalam pembangunan kesehatan terutama dalam PHBS, dan belum terpenuhinya ketersediaan tenaga kesehatan yang sesuai dengan kompetensinya. Oleh karenanya, penanganan KLB penyakit menular menjadi salah satu prioritas pembangunan kesehatan di Kabupaten Tangerang. Beberapa penyakit menular yang berpotensi menjadi KLB di Kabupaten Tangerang adalah penyakit DBD, leptospirosis dan difteri. Dari ketiga potensi tersebut, penyakit DBD merupakan penyakit menular yang sering terjadi di Kabupaten Tangerang.

Sebelum terjadi KLB, Pemerintah Kabupaten Tangerang sudah mengantisipasi melalui upaya fogging secara massal pada bulan Oktober 2015. Fogging dilaksanakan di tujuh belas titik rawan penyebaran nyamuk Aedes aegypti. Namun di penjelasan sebelumnya telah dikatakan bahwa upaya fogging tidak efektif dalam memberantas DBD dikarenakan fogging hanya membunuh nyamuk dewasa dan tidak membunuh jentik nyamuk. Padahal siklus hidup jentik nyamuk lebih panjang dari pada nyamuk dewasa. Sehingga jika yang dibunuh hanya nyamuk 
dewasanya saja, maka jentik nyamuk tetap bisa segera berkembang dan menjadi nyamuk dewasa yang dapat menyebarkan penyakit DBD. Fogging juga tidak dapat dilakukan di sembarang tempat. Sebelum diputuskan untuk dilakukan fogging, harus dipastikan terlebih dahulu lokasi di mana penderita digigit nyamuk tersebut. Sehingga, diperlukan kajian epidemiologi guna mengetahui ada tidaknya penderita DBD yang lain atau menemukan tersangka DBD dan melaksanakan pemeriksaan jentik pada radius 100 meter dari penderita. ${ }^{7}$ Menurut salah satu informan, kajian epidemiologi tidak selalu dilakukan mengingat keterbatasan sumber daya manusia yang mengerjakan kegiatan epidemiologi maupun surveilans di lingkungan pemerintah daerah dan puskesmas.

Pada saat KLB DBD terjadi di Kabupaten Tangerang tahun 2016, upaya pemberantasan yang dilakukan adalah (1) kegiatan PSN di semua wilayah Kabupaten Tangerang; (2) sosialisasi dan gerakan desa bebas jentik kepada kader; (3) penyelidikan epidemologi; (4) melaksanakan fogging sesuai kriteria dari hasil penyelidikan epidemologi; dan (5) penemuan serta penanganan korban secara tepat.

Upaya pemberantasan penyakit DBD dititikberatkan pada kegiatan menggerakkan potensi dan komitmen masyarakat dalam upaya pemantauan jentik berkala. Melalui kebijakan pembentukkan kader Jumantik di setiap wilayah yang melakukan pemantauan jentik setiap harinya. Pemerintah Kabupaten Tangerang telah menyadari bahwa upaya pemberantasan KLB DBD lebih efektif dilakukan melalui kegiatan PSN dari pada fogging. Bupati sudah menyebarkan surat edaran kepada masyarakat melalui RT dan sekolah-sekolah untuk senantiasa melakukan PSN guna menjaga kebersihan dan kesehatan lingkungan sekitar. Pemerintah Kabupaten Tangerang juga rutin mengadakan penyuluhan terutama untuk mengajarkan kepada masyarakat agar bisa menjadi Jumantik di rumahnya masing-masing. Pasca-KLB, pemerintah

Tangerang Waspada Siklus Tiga Tahunan DBD, https:// www.republika.co.id/berita/koran/urbana/16/02/03/ olym4b-tangerang-waspada-siklus-tiga-tahunan-dbd, diakses 26 September 2018. tetap melakukan upaya pembentukkan kader Jumantik. Misalnya, di Kecamatan Tigaraksa pada tahun 2017 telah menjadi wilayah bebas jentik nyamuk padahal tahun sebelumnya telah terjadi KLB DBD. ${ }^{8}$ Kegiatan penanggulangan KLB DBD terkendala faktor pertambahan jumlah penduduk dan peningkatan mobilitas penduduk Kabupaten Tangerang yang sejalan dengan semakin membaiknya sarana transportasi yang menyebabkan penyebaran virus DBD semakin mudah dan luas. Kegiatan penanggulangan KLB terkendala faktor perilaku dan partisipasi masyarakat yang masih kurang dalam mendukung kegiatan PSN.

Upaya yang dilakukan dalam mengantisipasi terjadinya KLB DBD di masa yang akan datang adalah pelatihan manajemen kasus terhadap petugas; penyediaan sarana dan prasarana untuk deteksi dini dan penanganan yang tepat dan cepat; promosi kesehatan yang berkualitas; dan peningkatan akses kesehatan. Kerja sama dengan lintas sektoral seperti SKPD terkait, kader kesehatan, RT, RW, tokoh masyarakat, dan tokoh agama dilakukan untuk meningkatkan pengetahuan dan keterampilan dalam deteksi dini kasus DBD agar segera dapat ditata laksana sesuai standar pelayanan medis.

Secara umum, pelaksanaan kebijakan penanggulangan KLB DBD di Kabupaten Tangerang terhambat faktor sumber daya manusia terutama ketersediaan epidemiolog. Menurut informan di Puskesmas Cikuya dan Dinas Kesehatan Kabupaten Tangerang, puskesmas di Kabupaten Tangerang mengalami kekurangan tenaga epidemiolog kesehatan. Bahkan di perkantoran Dinas Kesehatan Kabupaten Tangerang, hanya ada satu tenaga epidemiolog kesehatan. Padahal epidemiolog kesehatan sangat dibutuhkan dalam upaya penyelidikan kasus penyakit menular. Dalam UndangUndang Nomor 36 Tahun 2014 tentang Tenaga Kesehatan, epidemiolog kesehatan merupakan salah satu jenis tenaga kesehatan dalam kelompok tenaga kesehatan masyarakat. Tugas

Kabupaten Tangerang Canangkan Program 1 Rumah 1 Jumantik, http://dinkes.tangerangkab.go.id/ cisoka/2017/09/28/kabupaten-tangerang-canangkanprogram-1-rumah-1-jumantik/ diakses 26 September 2018. 
epidemiolog kesehatan adalah mendiagnosis masalah kesehatan; menentukan riwayat alamiah penyakit; serta memberikan informasi dalam rangka meningkatkan manajemen pelayanan kesehatan dan pengambilan keputusan.

Menurut informan di Puskesmas Cikuya, dokter, perawat dan bidan yang ada di puskesmas di Kabupaten Tangerang selain melakukan tugas danfungsi sesuai kewenangan dankompetensinya, juga melakukan tugas epidemiologi dan surveilans kesehatan masyarakat. Dokter selain melakukan upaya pengobatan kepada pasien, juga melakukan kegiatan epidemiologi seperti memegang beberapa program pengendalian penyakit menular yang di dalamnya termasuk kegiatan epidemiologi, surveilans, promosi kesehatan, dan lainnya. Dampak dari kondisi ini adalah ketika ada laporan penderita penyakit menular, dokter tidak bisa langsung melakukan penyidikan epidemiologi melainkan harus menunggu selesainya jam praktik dokter di puskesmas. Bahkan dengan keterbatasan waktu tersebut, sangat tidak memungkinkan bagi dokter untuk melakukan kegiatan surveilans rutin di wilayah kerja puskesmas yang biasanya meliputi lebih dari tujuh desa. Hal ini mengingat di kabupaten hanya ada puskesmas di tingkat kecamatan.

Selain masalah sumber daya manusia, pelaksanaan kebijakan penanggulangan KLB DBD juga terkendala masalah advokasi kebijakan di tingkat kecamatan dan kelurahan. Seperti diketahui bahwa upaya penanggulangan KLB DBD sangat bergantung pada komitmen pengurus lingkungan baik kepala RT, RW, lurah, dan camat. Hal ini mengingat kegiatan PSN bertujuan mengubah perilaku masyarakat untuk hidup bersih dan sehat sehingga dibutuhkan panutan dari tokoh masyarakat setempat. Upaya advokasi dilakukan kepada pengurus lingkungan tersebut oleh kepala puskesmas namun belum sepenuhnya melibatkan epedemiolog kesehatan. Dalam hal ini, upaya advokasi dapat dipermudah dengan penggunaan data-data kejadian penyakit menular yang disusun oleh epidemiolog kesehatan sehingga kebijakan yang diambil dapat tepat sasaran. Upaya advokasi kesehatan di tingkat kecamatan dan kelurahan juga belum didukung oleh adanya tenaga kesehatan yang bertugas di kantor kelurahan dan kecamatan. Advokasi dinilai akan lebih berhasil jika ada orang yang berkompeten di dalam sasaran advokasi. Advokasi di sini menurut Kementerian Kesehatan adalah upaya pendekatan dan motivasi terhadap pihak-pihak tertentu yang diperhitungkan dapat mendukung keberhasilan pembinaan perilaku hidup bersih dan sehat baik dari segi materi maupun nonmateri.

\section{Penutup \\ Simpulan}

Kondisi geografis Indonesia menyebabkan Indonesia termasuk negara endemis penyakit DBD yang ditularkan melalui gigitan nyamuk Aedes aegypt. Penyakit DBD pertama kali ditemukan di Kota Surabaya pada tahun 1968. Hingga kini, penyakit DBD ditemukan hampir di seluruh wilayah Indonesia dan tak jarang menimbulkan status wabah atau KLB. Kementerian Kesehatan mencatat, pada tahun 2014 terdapat sebanyak 1.081 kasus KLB DBD. Jumlah tersebut meningkat drastis pada tahun 2015, yaitu 8.030 kasus KLB DBD. Demikian juga dengan jumlah provinsi dan kabupaten yang melaporkan KLB DBD mengalami peningkatan, yaitu 5 provinsi dan 21 kabupaten pada tahun 2014 menjadi 7 provinsi dan 69 kabupaten pada tahun 2015. Kabupaten Tangerang merupakan salah satu daerah di Indonesia yang dinyatakan KLB DBD oleh Menteri Kesehatan. Setiap tahun, penyakit DBD terjadi di Kabupaten Tangerang dan puncaknya setiap tiga tahun sekali, yaitu tahun 2013 dan 2016. Dari tahun 2013 hingga 2015, tercatat ada sebanyak 373, 412, dan 371 kasus DBD. Jumlah tersebut mengalami peningkatan drastis pada tahun 2016 menjadi 1.253 kasus DBD dengan kejadian meninggal sebanyak 22 orang. Dengan kata lain, CFR DBD Kabupaten Tangerang pada tahun 2016 sebesar $1,75 \%$. CFR yang tinggi ini menandakan terlambatnya upaya pemberantasan penyakit DBD termasuk terlambatnya upaya pengobatan sehingga menyebabkan kematian pada penderita DBD.

Pemerintah Kabupaten Tangerang sudah mengantisipasi terjadinya KLB DBD tahun 2016, 
yaitu dengan melakukan upaya fogging secara massal pada bulan Oktober 2015. Pada saat KLB DBD tahun 2016, upaya pemberantasan dilakukan melalui: (1) kegiatan PSN di semua wilayah Kabupaten Tangerang; (2) sosialisasi dan gerakan desa bebas jentik kepada kader; (3) penyelidikan epidemologi; (4) melaksanakan fogging sesuai kriteria dari hasil penyelidikan epidemologi; dan (5) penemuan serta penanganan korban secara tepat.

Penyebaran DBD dikarenakan semakin membaiknya sarana transportasi dan tingginya mobilitas penduduk yang menyebabkan penyebaran virus DBD semakin mudah dan semakin luas. Kegiatan penanggulangan KLB terkendala faktor perilaku dan partisipasi masyarakat yang masih kurang dalam mendukung kegiatan PSN. Selain itu, faktor sumber daya manusia terutama ketersediaan epidemiolog kesehatan menjadi faktor penghambat penanggulangan KLB DBD. Masalah advokasi kebijakan di tingkat kecamatan dan kelurahan juga menjadi faktor penghambat. Upaya penanggulangan KLB DBD sangat bergantung pada komitmen pengurus lingkungan baik kepala RT, RW, lurah, dan camat. Upaya advokasi dilakukan kepada pengurus lingkungan tersebut oleh kepala puskesmas namun belum sepenuhnya melibatkan tenaga epedemiolog kesehatan.

\section{Saran}

Beberapa saran yang diberikan antara lain: pertama, perlu adanya koordinasi lintas sektor di Kabupaten Tangerang mengenai pentingnya melibatkan komitmen masyarakat dalam menjaga kebersihan dan kesehatan lingkungan yang mendukung penanggulangan KLB DBD. Kedua, pencegahan KLB DBD di Kabupaten Tangerang sebaiknya lebih menitikberatkan pada upaya PSN yang bertujuan mengubah perilaku masyarakat. Perlu adanya inovasi kegiatan seperti lomba sehat antardesa. Ketiga, DPR melalui fungsi legislasi perlu merevisi Undang-Undang Nomor 4 Tahun 1984 tentang Wabah Penyakit Menular agar upaya penanggulangan KLB melibatkan pihak terkait selain pemerintah dan masyarakat; upaya penanggulangan KLB tidak hanya dilakukan pada saat terjadinya KLB melainkan pada sebelum dan setelah KLB; perlu memperhatikan aspek intervensi pada lingkungan sehingga upaya penanggulangan KLB tidak hanya fokus pada manusia dan agen penyakitnya saja; serta perlu diatur mengenai sistem peringatan dini KLB. Selain itu, perlu ditinjau ulang mengenai kriteria penetapan status KLB. Apakah memungkinkan penetapan status KLB pada tingkatan wilayah kecamatan atau kelurahan? Mengingat terlalu banyak sumber daya yang dikerahkan ketika suatu kabupaten/kota dinyatakan KLB. Keempat, DPR perlu melakukan upaya pengawasan terhadap pelaksanaan kebijakan penanggulangan KLB DBD yang dilakukan pemerintah.

\section{DAFTAR PUSTAKA}

\section{Jurnal}

Dini, Amah Majidah Vidyah, dkk. (2010). Faktor Iklim dan Angka Insiden Demam Berdarah Dengue di Kabupaten Serang. Makara Journal of Health Research. Vol. 14, No. 1, hlm. 37-45.

Gubler, Duane. (2005). The Emergence of Epidemic Dengue Fever and Dengue Hemorrhagic Fever in The Americas: a Case of Failed Public Health Policy. Rev Panam Salud Publica. Vol 17, No.2, hlm. 221-224.

Hasyimi, H dan Mardjan Soekirno. (2004). Pengamatan Tempat Perindukan Aedes Aegypti pada Tempat Penampungan Air Rumah Tangga pada masyarakat Pengguna Air Olahan. Jurnal Ekologi Kesehatan. Vol. 3, No. 1, hlm. 37-42.

Khetarpal, Niyati dan Ira Khanna. (2016). Dengue Fever: Causes, Complications, and Vaccine Strategies. Journal of Immunology Research. Vol. 2016, hlm. 1-14.

Nedjadi, Taoufik, dkk. (2015). Tackling Dengue Fever: Current Status and Challenges. Virology Journal. Vol. 12, No. 212, hlm. 1-11.

Rothman, Alan L. dan Francis A. Ennis. (2016). Dengue Vaccine: The Need, The Challenges, and Progress. The Journal of Infectious Diseases. Vol. 214, No. 6, hlm. 825-827. 
Runge-Ranzinger, dkk. (2016). Dengue Contingency Planning: From Research to Policy and Practice. Plos Neglected Tropical Diseases. Vol. 10, No. 9, hlm. 1-16.

Singh, Amerjeet dan Andrew W Taylor-Robinson. (2017). Vector Control Interventions to Prevent Dengue: Current Situation and Strategies for Future Improvements to Management of Aedes in India. Journal of Infectious Disease and Pathology. Vol. 2. No. 1, hlm. 1-8.

\section{Buku}

Agustino, Leo. (2008). Dasar-Dasar Kebijakan Publik. Bandung: Penerbit Alfabeta.

Dinas Kesehatan Kabupaten Tangerang. (2017). Profil Kesehatan Kabupaten Tangerang. Banten: Dinas Kesehatan Kabupaten Tangerang.

Dunn, William N. (2003). Pengantar Analisis Kebijakan Publik. Yogyakarta: Gadjah Mada University Press.

Irianto, Koes. (2014). Epidemiologi Penyakit Menular dan Tidak Menular: Panduan Klinis. Bandung: Alfabeta.

Kementerian Kesehatan. (2011). Promosi Kesehatan di Daerah Bermasalah Kesehatan: Panduan bagi Petugas Kesehatan di Puskesmas. Jakarta: Kementerian Kesehatan.

Kementerian Kesehatan. (2016). Infodatin Situasi $D B D$ di Indonesia. Jakarta: Pusat Data dan Informasi, Kementerian Kesehatan.

Kementerian Kesehatan. (2016). Menkes: Dibanding Fogging, PSN 3M Plus Lebih Utama Cegah $D B D$. Jakarta: Kementerian Kesehatan.

Kementerian Kesehatan. (2018). Profil Kesehatan Indonesia Tahun 2017. Jakarta: Kementerian Kesehatan.

Nugroho, Riant. (2012). Public Policy: Dinamika Kebijakan, Analisis Kebijakan, dan Manajemen Kebijakan. Jakarta: PT Elex Media Komputindo.

WHO. (2009). Dengue: Guidelines for Diagnosis, Treatment, Prevention and Control. France: WHO.

\section{Internet}

13 Orang Meninggal, Kabupaten Tangerang Tetapkan KLB DBD, https://metro.tempo.co/ $\mathrm{read} / 742330 / 13$-orang-meninggal-kabupatentangerang-tetapkan-klb-dbd, diakses 6 September 2018.
Bersama 10 Daerah Lainnya, Kabupaten Tangerang Dinyatakan KLB Demam Berdarah, http:// poskotanews.com/2016/02/05/kabupatentangerang-dinyatakan-klb-demam-berdarah/, diakses 6 September 2018.

Demam Berdarah Dengue (DBD), http://www. depkes.go.id/development/site/depkes/index. php?cid $=1-17042500004 \&$ id $=$ demam-berdarahdengue-dbd-, diakses 26 September 2018.

Demam Berdarah di Kabupaten Tangerang Makin Parah, http://wartakota.tribunnews. com/2016/03/29/demam-berdarah-di-kabupatentangerang-makin-parah, diakses 6 September 2018.

Efek Vaksin DBD Bisa Berbahaya, Ini Penjelasan WHO dan IDAI, https://sains.kompas.com/ $\mathrm{read} / 2017 / 12 / 08 / 170000223 /$ efek-vaksin-dbdbisa-berbahaya-ini-penjelasan-who-dan-idai, diakses 26 September 2018.

Epidemiologi dan Pemberantasan Demam Berdarah Dengue (DBD) di Indonesia, http://repository. usu.ac.id/bitstream/123456789/3673/3/fkmfazidah3.pdf.txt, diakses 26 September 2018.

Implementasi Kebijakan Pemerintah mengenai Pengendalian Penyakit Demam Berdarah (DBD) dalam Rangka Meningkatkan Derajat Kesehatan Masyarakat di Kota Semarang, http://ejournal.stikestelogorejo.ac.id/index.php/ ilmukeperawatan/article/viewFile/289/313, diakses 26 September 2018.

Kabupaten Tangerang Canangkan Program 1 Rumah 1 Jumantik, http://dinkes.tangerangkab. go.id/cisoka/2017/09/28/kabupaten-tangerangcanangkan-program-1-rumah-1-jumantik/, diakses 26 September 2018.

Kendalikan DBD dengan PSN 3M Plus, http:// www.depkes.go.id/article/view/16020900002/ kendalikan-dbd-dengan-psn-3m-plus.html, diakses tanggal 26 September 2018.

Tangerang Waspada Siklus Tiga Tahunan DBD, https://www.republika.co.id/berita/koran/ urbana/16/02/03/o1ym4b-tangerang-waspadasiklus-tiga-tahunan-dbd, diakses 26 September 2018. 